\title{
ANALISIS BEBAN KERJA OPERATOR PAPER MESIN \#6 PT. INDAH KIAT PULP AND PAPER TBK MENGGUNAKAN METODE CARDIOVASCULAR LOAD (CVL) DAN SUBJECTIVE WORKLOAD ASSESSMENT TECHNIQUE ( SWAT )
}

\author{
Faradila Ananda Yul, Sat Rudi Setiyawan \\ ${ }^{1,2}$ Program Studi Teknik Industri, Fakultas Teknik, Universitas Muhammadiyah Riau, Jln. \\ Tuanku Tambusai Ujung, Pekanbaru, Riau. \\ E-mail : faradila@umri.ac.id
}

\begin{abstract}
PT. Indah Kiat Pulp and Paper Tbk is a manufacturing company engaged in pulp processing, one of the largest paper machines in Perawang is Paper machine \#6. Paper machine \#6 operates continuously 24 hours and to support the production process, the employee's working hours are divided into 3 work shifts. The problem that occurs in this paper machine is the high number of work accidents due to the high workload felt by the operator, causing the operator to be physically and mentally exhausted. The study was conducted on Wet End, Dry End, Chemical, Winder and Thimons production station operators, namely measuring physical workload using the Cardiovascular Load $(C V L)$ method and measuring mental workload using the Subjective Workload Assessment Technique (SWAT) method. The results of the calculation of the CVL method that the greatest physical workload in shift 3 group B occurs in the Thimons 1 operator having a \% CVL value of $46.62 \%$ with a recommendation that repairs are needed and the Wet End 3 operator with a \% CVL value of $44.74 \%$ with information repair is needed. Based on the CVL results, as many as 12 employees experienced a physical workload. In contrast to shift heads and Desktop Control System (DCS) operators, the perceived workload tends to be more of a mental burden. Research on shift heads and DCS operators uses the method, the SWAT method is used to measure mental workload. The research was conducted by direct observation and interviews, then the shift heads and DCS operators were asked to sort 27 SWAT cards consisting of Time Load (T), Mental Effort Load (E) and Psychological Stress Load (S). The results of the SWAT card sorting were processed using the DosBox 0.74 application, after which the values of Time, Effort and Stress (T.E.S) were converted. Based on the calculation of the mental workload of the shift head, the most influential factor is the Time factor with a value of 60.44\% followed by the Effort and Stress factors with a value of $29.64 \%$ and $9.92 \%$. It is similar to the DCS operator, the most influential factor is the Time factor with a value of $68.57 \%$ followed by the Effort and Stress factors with a value of $23.29 \%$ and $8.13 \%$, respectively. Time burden is the main factor felt by employees because of the demands of work that require employees to be fast in carrying out every activity.
\end{abstract}

Keywords: Cardiovascular Load (CVL), Mental Effort Load(E), Psychological Stress Load (S), Subjective Workload Assessment Technique (SWAT), Time Load (T)

\section{ABSTRAK}

PT. Indah Kiat Pulp and Paper Tbk merupakan perusahaan industri manufaktur yang bergerak dibidang pengolahan bubur kertas, salah satu mesin kertas terbesar di Perawang adalah Paper mesin \#6. Paper mesin \#6 beroperasi secara kontinyu 24 jam dan untuk mendukung proses produksi tersebut jam kerja karyawan dibagi menjadi 3 shift kerja. Permasalahan yang terjadi pada paper mesin ini adalah tingginya angka kecelakaan kerja dikarenakan

SURYA TEKNIKA Vol. 8 No. 2, Desember 2021: 302-309 
tingginya beban kerja yang dirasakan oleh operator sehingga menyebabkan operator kelelahan baik fisik maupun mental. Penelitian dilakukan pada operator stasiun produksi Wet End, Dry End, Chemical, Winder dan Thimons yaitu dilakukan pengukuran beban kerja fisik dengan menggunakan metode Cardiovascular Load (CVL) dan pengukuran beban kerja mental dengan metode Subjective Workload Assessment Technique (SWAT). Hasil perhitungan metode CVL bahwa beban kerja fisik yang paling besar pada shift 3 grup B terjadi pada operator Thimons 1 memiliki nilai \% CVL sebesar 46,62 \% dengan rekomendasi diperlukan perbaikan dan operator Wet End 3 dengan nilai \% CVL sebesar 44,74 \% dengan keterangan diperlukan perbaikan. Berdasarkan hasil CVL, sebanyak 12 karyawan mengalami beban kerja fisik. Berbeda dengan kepala shift dan operator Dekstop Control System (DCS), beban kerja yang dirasakan cenderung lebih ke beban mental. Penelitian pada kepala shift dan operator DCS menggunakan metode, metode SWAT digunakan untuk mengukur beban kerja mental. Penelitian dilakukan dengan cara pengamatan dan wawancara secara langsung, selanjutnya kepala shift dan operator DCS diminta untuk mengurutkan 27 lembar kartu SWAT yang terdiri dari Time Load(T), Mental Effort Load(E) dan Psycological Stress Load (S). hasil pengurutan kartu SWAT diolah dengan menggunakan aplikasi DosBox 0.74, setelah itu dilakukan pengkonversian nilai dari Time, Effort dan Stress (T.E.S). Berdasarkan perhitungan beban kerja mental kepala shift, faktor yang paling berpengaruh adalah faktor Time dengan nilai 60,44\% diikuti faktor Effort dan Stress dengan nilai 29,64\% dan 9,92\%. Hal serupa dengan operator DCS, faktor yang paling berpengaruh adalah faktor Time dengan nilai 68,57\% diikuti faktor Effort dan Stress dengan nilai $23,29 \%$ dan $8,13 \%$. Beban waktu menjadi faktor utama yang dirasakan oleh karyawan karena tuntutan pekerjaan yang mengharuskan karyawan harus cepat dalam melakukan setiap aktivitas.

Kata kunci : Cardiovascular Load (CVL), Mental Effort Load (E), Psycological Stress Load (S), Subjective Workload Assessment Technique (SWAT), Time Load (T)

\section{PENDAHULUAN}

PT Indah kiat pulp and paper Tbk merupakan salah satu perusahaan manufaktur yang bergerak dalam bidang industri kertas, dengan produk utama yaitu pulp atau bubur kertas, kertas putih atau fine paper, carton box atau kertas packing, dan Tissue. Terdapat Sembilan unit mesin kertas yang beroperasi di Perawang dan Paper Mesin \#6 merupakan mesin kertas terbesar.

Pada proses pembuatan kertas di Paper mesin \#6 terdapat lima proses produksi yaitu Dekstop Control System (DCS), Chemical and Stock preparation, Wet end proses, Drying proses, Winding proses, dan Thimons proses. Proses produksi kertas berlangsung secara kontinyu 24 jam, untuk mendukung proses produksi tersebut dibentuk 4 grup karyawan proses produksi yaitu grup A, grup B, grup $\mathrm{C}$ dan grup $\mathrm{D}$, jadwal kerja karyawan produksi adalah 5 hari kerja 2 hari libur dengan pembagian jam kerja untuk shift 1 pukul 07:00 s/d 15:00, shift 2 pukul 15:00 s/d 23:00, dan shift 3 pukul 23:00 s/d 07:00.

Berdasarkan wawancara terhadap operator Wet end dan dry end, pada saat terjadi reject seperti kertas putus/web break, target yang diberikan oleh manajemen dirasakan sangat singkat, target untuk web break pada Pre dryer mesin adalah 15 menit, target untuk web break pada Sizepress mesin adalah 10 menit, target untuk web break pada Reel mesin adalah 5 menit, target waktu yang diberikan dirasakan terlalu singkat dikarenakan operator juga harus melakukan cleaning pada semua area mesin, operator bekerja secara ekstra untuk mengejar target, akibatnya sering terjadi kecelakaan kerja. data kecelakaan kerja yang terjadi di Paper mesin \#6 dapat dilihat pada tabel 1.1.

Operator mesin Winder merasakan tingginya beban kerja ketika produksi roll ekspor, dalam satu kali turun terdapat $12 \mathrm{~s} / \mathrm{d} 13$ deckle atau ukuran small roll, dan untuk satu jumbo roll terdapat 10 (sepuluh) kali turunan hasil produksi, yang berarti dalam 1 jumbo roll menghasilkan 120 small roll, Ketika dua mesin winder memproduksi roll ekspor sering terjadi penumpukan pada area winder dan jalur conveyor, di tambah dengan pekerjaan melakukan pengeleman, pengecekan kualitas small roll, serta penempelan id barcode pada masing-masing small roll sedangkan personil hanya terbatas.

Dilakukan wawancara terhadap operator mesin thimons, operator thimons mengeluhkan kondisi operator yang hanya berjumlah 1 orang harus mengoperasikan 3 unitmesin thimons, dan mengoperasikan crane untuk pengangkatan material dari basement ke lantai 1.

Berbeda halnya dengan Kepala shift dan operator Dekstop Control System (DCS), beban kerja 
yang dirasakan cenderung lebih ke beban mental, seorang kepala shift harus mengatur sebuah tim, dengan karakter operator yang berbeda-beda, operator DCS mengeluhkan aktivitas yang harus dilakukan dalam mengendalikan 9 unit komputer, operator DCS harus cepat menemukan penyebab masalah mesin, penyebab terjadinya kertas putus dan mengatur material pendukung bahan baku kertas.

Beban kerja dirasakan oleh semua operator di semua bagian mesin di karenakan kekurangan personil, dengan pola kerja shift, pada schedule biasa operator wajib masuk untuk lembur menyelesaikan target pekerjaan, bahkan ada yang melanjutkan kerja dari pukul 15:00 s/d 07:00 untuk menggantikan personil yang cuti, sedangkan pukul 15:00 harus masuk kerja kembali, waktu istirahat yang kurang menjadi salah satu penyebab terjadinya kecelakaan kerja seperti disampaikan oleh pengurus safety paper mesin \#6, dalam beberapa tahun terakhir sering terjadi kecelakaan yang di alami oleh operator paper mesin \#6

Berikut data kecelakaan yang terjadi pada periode September 2014 hingga Oktober 2020 :

Tabel 1.1. Data kecelakaan kerja karyawan paper mesin \#6

\begin{tabular}{|c|c|c|c|c|}
\hline Kejadian & Tanggal & Jam & Lokasi & $\begin{array}{l}\text { Akibat dan sebab } \\
\text { dari kecelakaan }\end{array}$ \\
\hline kejadian 1 & 14/9/2014 & 02.45.wib & winder 2 & $\begin{array}{l}\text { Kaki terjepit roll dan winder drum } \\
\text { saat melakukan penyambungan } \\
\text { kertas }\end{array}$ \\
\hline kejadian 2 & $14 / 4 / 2015$ & 14.31.wib & calender 1 & $\begin{array}{l}\text { Saat memperhatikan proses } \\
\text { penyambungan kertas, conveyor } \\
\text { fibron bergerak dan membentur } \\
\text { kepala }\end{array}$ \\
\hline kejadian 3 & $11 / 02 / 2016$ & 20.00 wib & $\begin{array}{l}\text { forming } \\
\text { section }\end{array}$ & $\begin{array}{l}\text { Paha kiri terasa sakit, jatuh dari } \\
\text { ketinggian } \pm 1.5 \quad \text { meter ketika } \\
\text { melakukan pengecekan head box }\end{array}$ \\
\hline kejadian 4 & $11 / 08 / 2016$ & 15.30 wib & $\begin{array}{l}\text { basement } \\
\text { press } \\
\text { section }\end{array}$ & $\begin{array}{l}\text { Wajah dan kedua mata merah dan } \\
\text { perih (mata kabur) terkena percikan } \\
\text { bahan kimia sewaktu meperbaiki } \\
\text { sigh glass melakukan pengecekan } \\
\text { tekanan }\end{array}$ \\
\hline kejadian 5 & $15 / 09 / 2016$ & 04.00 wib & mcc mesin & $\begin{array}{l}\text { Mata kanan dan kiri terasa perih } \\
\text { terkena debu ketika melakukan } \\
\text { pengecekan ac sirkulasi udara mcc }\end{array}$ \\
\hline kejadian 6 & 05/12/2016 & 07.30 wib & wp-3 & $\begin{array}{l}\text { Mata kiri terasa perih terkena debu } \\
\text { sewaktu melintas di wp-3 ke lokasi } \\
\text { kerja }\end{array}$ \\
\hline kejadian 7 & 02/06/2017 & 06.40.wib & winder 2 & $\begin{array}{lll}\text { Jari tangan } & \text { terjepit } & \text { roll sheet } \\
\text { threader } & \text { saat } & \text { melakukan } \\
\text { penyambungan kertas } & \end{array}$ \\
\hline kejadian 8 & $12 / 05 / 2017$ & 19.50.wib & $\begin{array}{l}\text { press } \\
\text { section }\end{array}$ & $\begin{array}{l}\text { Jari manis tangan kanan terjepit } \\
\text { handrail pickup roll }\end{array}$ \\
\hline kejadian 9 & $11 / 01 / 2018$ & 12.30.wib & thimon $\mathrm{c}$ & $\begin{array}{l}\text { Jari tangan kiri terjepit pada small } \\
\text { roll dan roll wrapping }\end{array}$ \\
\hline kejadian 10 & $5 / 1 / 2019$ & 10.05.wib & $\begin{array}{l}\text { pre dryer } \\
\text { hood }\end{array}$ & $\begin{array}{l}\text { kepala robek terbentur manual valve } \\
\text { steam }\end{array}$ \\
\hline kejadian 11 & $21 / 4 / 2019$ & 11.30.wib & winder 2 & $\begin{array}{l}\text { jari telunjuk tangan kanan terjepit } \\
\text { core dan beam }\end{array}$ \\
\hline kejadian 12 & 2/2/2020 & 18.20.wib & winder 1 & lengan kiri lebam terjepit small roll \\
\hline kejadian 13 & $11 / 10 / 2020$ & 18.20.wib & sizepress & $\begin{array}{l}\text { kening robek terbentur nozzle hose } \\
\text { udara }\end{array}$ \\
\hline
\end{tabular}

Sumber: PT. IKPP, 2021

Data di atas menunjukkan bahwa kecelakan kerja yang terjadi pada paper mesin \#6 cukup tinggi, berdasarkan hasil wawancara dengan dari karyawan pada stasiun produksi paper mesin \#6 yang mengeluhkan beban kerja yang tinggi, beban kerja yang tinggi akan menimbulkan kelelahan sehingga membuat konsentrasi karyawan berkurang dan mengakibatkan kecelakaan kerja.

Berdasarkan latar belakang di atas perlu dilakukan pengukuran beban kerja dengan menggunakan metode Cardiovascular Load (CVL), metod ini dilakukan dengan membandingkan antara pengukuran denyut nadi istirahat dan pengukuran denyut nadi kerja. Sedangkan untuk beban kerja mental digunakan analisis dengan menggunakan metode Subjective Workload Assesment Technique (SWAT), metode ini dilakukan dengan penilaian subjektif terhadap responden yang mengalami beban kerja mental pada stasiun produksi Paper mesin \#6.

\section{Beban kerja}

Beban kerja merupakan suatu kondisi pekerjaan dengan beberapa uraian tugas yang wajib dikerjakan sesuai target atau batas waktu yang telah ditentukan. Beban kerja adalah tingkatan pekerjaan yang harus ditanggung oleh suatu unit organisasi atau pemangku jabatan dan merupakan hasil kali antara norma waktu dan volume (Achyana,2016). Salah satu teknik manajemen untuk mendapatkan informasi jabatan adalah dengan melakukan pengukuran beban kerja melalui proses penelitian yang dilakukan secara analisis. Maksud dari informasi jabatan tersebut dapat digunakan untuk menyempurnakan sumberdaya manusia dan aparatur suatu lembaga (Sastra,2017)

Munculnya beban kerja diakibatkan adanya interaksi antara tugas yang diberikan kepada operator. Faktanya faktor fisik dan faktor psikologis saling berpengaruh. Untuk itu diperlukan pengukuran beban kerja pada suatu perusahaan agar faktor fisik dan faktor psikologis manusia dalam pekerjaannya diketahui. Sehingga tidak berakibat pada motivasi dan performansi kerja.

Faktor-faktor yang mempengaruhi beban kerja menurut (Achyana,2016) adalah sebagai berikut:

a. Faktor eksternal adalah beban kerja yang berasal dari luar tubuh:

1. Tugas yang dilakukan bersifat fisik, diantaranya tempat kerja, peralatan, kondisi kerja, sikap kerja, tata ruang dan stasiun kerja. Untuk tugas yang bersifat mental diantaranya training atau pelatihan, tanggung jawab, tingkat kesulitan dan kompleksitas suatu pekerjaan.

2. Manajemen kerja diantaranya kerja shift, sistem gaji, struktur organisasi, wewenang atau tugas, waktu istirahat dan waktu kerja. 
3. Wring stresor yang terdiri dari lingkungan kerja biologis, lingkungan kerja fisik, lingkungan kerja kimiawi dan lingkungan kerja psikologis.

b. Faktor internal adalah faktor yang timbul dari dalam tubuh karena terjadi reaksi beban kerja eksternal (Strain) atau reaksi tubuh. faktor internal ini meliputi keadaan fisik, kodisi kesehatan, keadaan gizi, umur dan jenis kelamin. Sedangkan faktor psikis meliputi keinginan, kepuasan, motivasi kepercayaan dan persepsi.

\section{Metode Cardiovascular Load (CVL)}

Metode ini dilakukan dengan cara mengukur denyut nadi. pengukuran denyut nadi dapat dilakukan dengan menggunakan alat bantu Oxymeter. Oxymeter merupakan sensor yang dijepitkan pada jari tangan. Pengukuran denyut nadi dapat juga dilakukan dengan cara manual menggunakan alat bantu stopwatch, rumus pengukurannya adalah sebagai berikut:

Denyut nadi $\left(\frac{\text { nadi }}{\text { menit }}\right)=\frac{10 \text { denyut }}{\text { waktu perhitungan }} \times 60$ Denyut nadi yang diukur ada beberapa jenis yaitu:

1. DNI (Denyut Nadi Istirahat) yang merupakan rata-rata denyut nadi sebelum melakukan pekerjaan

2. DNI (Denyut Nadi Kerja) yang merupakan rata-rata denyut nadi pada saat melakukan pekerjaan

3. Nadi kerja merupakan selisih antara denyut nadi istirahat dengan denyut nadi kerja Adapun penentuan klasifikasi beban kerja berdasarkan perbandingan denyut nadi kerja dengan denyut nadi maksimum dinyatakan dalam beban kerja Cardiovascular Load (CVL) (Purwaningsih, 2017) Rumus untuk menghitung persentase Cardiovascular Load (\%CVL) adalah sebagai berikut:

$$
\% C V L=\frac{100 \times \text { (Denyut nadi kerja }- \text { Denyut nadi istirahat) }}{\text { (Denyut nadi maksimum }- \text { Denyut nadi istirahat) }}
$$

Dimana :

1. Denyut nadi maksimum untuk laki-laki adalah (220 - umur)

2. Denyut nadi maksimum untuk perempuan adalah (200 - umur)

Kemudian (Diniaty,2016) hasil perhitungan persentase CVL tersebut akan dibandingkan dengan standar klasifikasi sebagai berikut:

\begin{tabular}{|c|c|}
\hline$<30 \%$ & Tidak terjadi kelelahan \\
\hline $30<60 \%$ & Diperlukan perbaikan \\
\hline $60<80 \%$ & Kerja dalam waktu singkat \\
\hline $80<100 \%$ & Diperlukan tindakan segera \\
\hline$>100 \%$ & Tidak boleh beraktivitas \\
\hline
\end{tabular}

\section{Metode Subjective Workload Assesment Technique (SWAT)}

Penerapan teknik yang di rencanakan untuk melakukan penetapan waktu kerja yang diperoleh seorang pekerja dalam menyelesaikan suatu pekerjaan pada tingkat prestasi yang telah ditentukan disebut pengukuran beban kerja.pengukuran beban kerja dibagi menjadi dua bagian:

a) Pengukuran beban kerja Objective meliputi

1) Eye blink measurement

2) Heart rate measurement

3) Iscan measurement

b) Pengukuran beban kerja Subjective meliputi:

1) Subjective Workload Assesment Technique (SWAT)

2) NASA TLX

3) Haper Cooper Rating

4) Task difficult scale

Metode Subjective Workload Assesment Technique (SWAT) dikembangkan pada Aerospace Medical Laboratory Wright-patterso Air Force Base, Ohio, USA oleh Harry G.Armstrong, SWAT dikembangkan untuk menjawab pertanyaan bagaimana cara mengukur beban kerja dalam lingkungan yang sebenarnya. Subjective Workload Assesment Technique (SWAT) adalah prosedur pemberian skala yang disalin untuk tugas penting yang banyak dari seseorang /individu yang berpengaruh pada mental serta berhubungan dengan pelaksanaan/performansi tugas yang bervariasi. Metode ini dikembangkan oleh Reid dan Nygren dengan menggunakan dasar metode pengskalaan conjoint. SWAT berbeda dengan pengukuran subjektif lainya karna dikembangkan dengan teliti dan akar pada teori pengukuran formal, khususnya teori pengukuran conjoint (Hutabarat,2018). Pengumpulan data dengan metode analisis SWAT dilakukan melalui pemakaian kartu-kartu kombinasi beban kerja mental, yaitu berupa lembaran yang dibuat secara khusus dan berjumlah 27 buah (Saputra dkk,2019).

Menurut metode SWAT, terdapat tiga ukuran beban kerja dalam performa kerja manusia diantaranya adalah:

1. Time Load (T) yang terdiri dari tiga kategori

1. Time Load rendah

2. Time Load menengah

3. Time Load tinggi

2. Mental Effort Load (E) yang terdiri dari tiga kategori

1. Mental Effort Load rendah

2. Mental Effort Load menengah

3. Mental Effort Load tinggi

3. Psychological Stress Load (S) 
1. Psychological Stress Load rendah

2. Psychological Stress Load menengah

3. Psychological Stress Load tinggi

Definisi dari ukuran beban kerja diatas adalah sebagai berikut:

a. Time Load: menunjukkan tersedianya jumlah waktu perncanaan tugas, pelaksanaan tugas dan monitoring tugas.

b. Mental Effort Load: melakukan praduga dan perkiraan banyaknya usaha mental dalam rencana yang diperlukan dalam melaksanakan tugas.

c. Psychological Stress Load: melakukan

pengukuran tingkat resiko, tingkat frustasi,

kemudian menghubungkannya dengan

penampilan atau performansi tugas.

A. Tahapan metode SWAT

Dalam melakukan penelitian dengan menggunakan metode SWAT terdapat beberapa tahapan diantaranya sebagai berikut:

1. Fase Pengembangan Skala (Scale Development)

Pada fase ini responden diberikan pilihan untuk melakukan pengurutan kartu kombinasi SWAT yang berjumlah 27 kartu dengan tiga variabel deskripsi beban kerja yaitu Time, Effort dan Stress. dimulai dari tingkatan dengan kategori yang paling rendah hingga kategori yang paling tinggi. mulai. Hal ini dilakukan untuk mendapatkan hasil beban kerja pada masingmasing individu.

2. Tes aksioma (Axiom test)

Tes aksioma bertujuan untuk melakukan uji kekonsistenan dan kesesuaian model aditif terhadap pengurutan kartu yang telah dihasilkan. Langkah pertama pada axiom test adalah prototype axiom test yang bertujuan menguji data pengurutan kartu apakaah sesuai dengan model aditif pada prototype yang ada. apabila besar nilai pelanggarannya $<20$ maka sifat dasar model aditif pada pengurutan kartu terpenuhi. artinya prototype scaling solution (PSS) apabila besar nilai pelanggarannya >20 maka dilakukan Individual axiom test (ISS) jika setelah dilakukan ISS nilai pelanggarannya >20 maka lebih baik data penelitian tersebut di keluarkan dari penelitian.

3. Tahap pemberian nilai (Event scoring)

Pada tahap ini responden diberikan pertanyaan dalam bentuk kuisioner, kuisioner berisi beberapa aktivitas pekerjaan yang biasa dilakukan kemudian ditanyakan pekerjaan tersebut sesuai dengan rating skala SWAT mulai dari skala 1 sampai dengan 3 untuk masing-masing dimensi Time, Effort dan Stress. Setelah kuisioner diisi oleh responden selanjutnya rating tersebut ditransformasikan dengan skala SWAT yang dihasilkan dari pengolahan data scaling solution untuk mengetahui tingkatan beban kerja mental yang diterima.

\section{HASIL DAN PEMBAHASAN}

\subsection{Pengukuran beban kerja fisik menggunakan metode Cardiovascular Load (CVL)}

Perhitungan persentase Cardiovascular Load (CVL) adalah sebagai berikut:

\%CVL

$=\frac{100 \times(\text { Denyut Nadi Kerja }- \text { Denyut Nadi Istirahat })}{\text { Denyut Nadi Maksimum }- \text { Denyut Nadi Istirahat }}$

$$
\begin{gathered}
\% \mathrm{CVL}=\frac{100 \times(98,5-75,5)}{191-75,5} \\
\% \mathrm{CVL}=\frac{2300}{115,5} \\
\% \mathrm{CVL}=19,91
\end{gathered}
$$

\begin{tabular}{|c|c|c|c|c|c|c|c|c|c|}
\hline Grup & Nama & Umur & DNK & $\begin{array}{c}\text { DNK } \\
\text { rata-rata }\end{array}$ & DNI & $\begin{array}{c}\text { DNI } \\
\text { rata-rata }\end{array}$ & $\begin{array}{c}\text { DN } \\
\max \end{array}$ & $\% \mathrm{CVL}$ & Keterangan \\
\hline \multirow{16}{*}{ D } & Wet End 1 & 29 & \begin{tabular}{|l|}
93 \\
104 \\
\end{tabular} & 98,5 & $\begin{array}{l}71 \\
80 \\
\end{array}$ & 75,5 & 191 & 19,91 & $\begin{array}{c}\text { Tidak terjadi } \\
\text { kelelahan }\end{array}$ \\
\hline & Wet End 2 & 35 & \begin{tabular}{|l|}
77 \\
110 \\
\end{tabular} & 93,5 & \begin{tabular}{|l|}
68 \\
84 \\
\end{tabular} & 76 & 185 & 16,06 & $\begin{array}{c}\begin{array}{c}\text { Tidak terjadi } \\
\text { kelelahan }\end{array} \\
\end{array}$ \\
\hline & Wet End 3 & 36 & $\begin{array}{l}102 \\
99 \\
\end{array}$ & 100,5 & $\begin{array}{l}68 \\
79 \\
\end{array}$ & 73,5 & 184 & 24,43 & $\begin{array}{c}\text { Tidak terjadi } \\
\text { kelelahan }\end{array}$ \\
\hline & Dry End 1 & 28 & \begin{tabular}{l|l|}
104 \\
141 \\
\end{tabular} & 122,5 & $\begin{array}{ll}81 \\
100 \\
\end{array}$ & 90,5 & 192 & 31,53 & $\begin{array}{c}\text { Diperlukan } \\
\text { perbaikan }\end{array}$ \\
\hline & Dry End 2 & 27 & $\begin{array}{l}109 \\
102 \\
\end{array}$ & 105,5 & \begin{tabular}{|l|}
63 \\
78 \\
\end{tabular} & 70,5 & 193 & 28,57 & $\begin{array}{c}\text { Tidak terjadi } \\
\text { kelelahan }\end{array}$ \\
\hline & Dry End 3 & 30 & $\begin{array}{l}99 \\
113 \\
\end{array}$ & 106 & $\begin{array}{l}80 \\
90 \\
\end{array}$ & 85 & 190 & 20,00 & $\begin{array}{c}\text { Tidak terjadi } \\
\text { kelelahan }\end{array}$ \\
\hline & Chemical 1 & 37 & $\begin{array}{l}85 \\
99 \\
\end{array}$ & 92 & $\begin{array}{l}77 \\
82 \\
\end{array}$ & 79,5 & 183 & 12,08 & $\begin{array}{c}\text { Tidak terjadi } \\
\text { kelelahan }\end{array}$ \\
\hline & Chemical 2 & 35 & \begin{tabular}{|l|}
90 \\
94 \\
\end{tabular} & 92 & $\begin{array}{l}80 \\
82 \\
\end{array}$ & 81 & 185 & 10,58 & $\begin{array}{c}\begin{array}{c}\text { Tidak Terjadi } \\
\text { kelelahha }\end{array} \\
\end{array}$ \\
\hline & Chemical 3 & 24 & \begin{tabular}{|l|}
88 \\
98 \\
\end{tabular} & 93 & $\begin{array}{l}65 \\
80 \\
\end{array}$ & 72,5 & 196 & 16,60 & $\begin{array}{c}\begin{array}{c}\text { Tidak terjadi } \\
\text { kelelahan }\end{array} \\
\end{array}$ \\
\hline & Winder 1 & 28 & $\begin{array}{l}109 \\
134 \\
\end{array}$ & 121,5 & $\begin{array}{l}67 \\
112 \\
\end{array}$ & 89,5 & 192 & 31,22 & $\begin{array}{c}\text { Diperlukan } \\
\text { perbaikan }\end{array}$ \\
\hline & Winder 2 & 24 & \begin{tabular}{|l|}
99 \\
155 \\
\end{tabular} & 127 & $\begin{array}{l}86 \\
94 \\
\end{array}$ & 90 & 196 & 34,91 & $\begin{array}{c}\text { Diperlukan } \\
\text { perbaikan }\end{array}$ \\
\hline & Winder 3 & 26 & $\begin{array}{l}108 \\
130 \\
\end{array}$ & 119 & $\begin{array}{l}81 \\
90 \\
\end{array}$ & 85,5 & 194 & 30,88 & $\begin{array}{c}\text { Diperlukan } \\
\text { perbaikan }\end{array}$ \\
\hline & Winder 4 & 26 & $\begin{array}{l}111 \\
120 \\
\end{array}$ & 115,5 & $\begin{array}{l}85 \\
90 \\
\end{array}$ & 87,5 & 194 & 26,29 & $\begin{array}{c}\text { Tidak terjadi } \\
\text { kelelahan }\end{array}$ \\
\hline & Winder 5 & 27 & $\begin{array}{l}102 \\
113 \\
\end{array}$ & 107,5 & $\begin{array}{l}68 \\
95 \\
\end{array}$ & 81,5 & 193 & 23,32 & $\begin{array}{c}\text { Tidak Terjadi } \\
\text { kelelahan }\end{array}$ \\
\hline & Winder 6 & 24 & $\begin{array}{l}80 \\
90 \\
\end{array}$ & 85 & $\begin{array}{l}69 \\
81\end{array}$ & 75 & 196 & 8,26 & $\begin{array}{c}\text { Tidak terjadi } \\
\text { kelelahan }\end{array}$ \\
\hline & Thimons 1 & 43 & \begin{tabular}{|l|l|}
99 \\
112 \\
\end{tabular} & 105,5 & $\begin{array}{l}82 \\
99 \\
\end{array}$ & 90,5 & 177 & 17,34 & $\begin{array}{c}\begin{array}{c}\text { Tidak Terjadi } \\
\text { kelelahan }\end{array} \\
\end{array}$ \\
\hline
\end{tabular}

Tabel 3.1. Perhitungan persentase CVL shift 1 grup D

Sumber: Pengolahan data CVL, 2021

Tabel 3.2. Perhitungan persentase CVL shift 2 grup A 


\begin{tabular}{|c|c|c|c|c|c|c|c|c|c|}
\hline Grup & Nama & Umur & DNK & $\begin{array}{c}\text { DNK } \\
\text { rata-rata }\end{array}$ & DNI & \begin{tabular}{|c|} 
DNI \\
rata-rata
\end{tabular} & $\begin{array}{l}\mathrm{DN} \\
\max \end{array}$ & $\% \mathrm{CVL}$ & Ke terangan \\
\hline \multirow{16}{*}{ A } & Wet End 1 & 36 & $\begin{array}{l}71 \\
102\end{array}$ & 86,5 & $\begin{array}{l}63 \\
82\end{array}$ & 72,5 & 184 & 12,56 & $\begin{array}{c}\text { Tidak terjadi } \\
\text { kelelahan }\end{array}$ \\
\hline & Wet End 2 & 32 & \begin{tabular}{c|}
90 \\
120
\end{tabular} & 105 & \begin{tabular}{|l|}
70 \\
98
\end{tabular} & 84 & 188 & 20,19 & $\begin{array}{c}\text { Tidak terjadi } \\
\text { kelelahan }\end{array}$ \\
\hline & Wet End 3 & 34 & $\begin{array}{ll}91 \\
105 \\
\end{array}$ & 98 & $\begin{array}{l}80 \\
77 \\
\end{array}$ & 78,5 & 186 & 18,14 & $\begin{array}{c}\text { Tidak terjadi } \\
\text { kelelahan }\end{array}$ \\
\hline & Dry End 1 & 28 & \begin{tabular}{ll|}
111 \\
144 \\
\end{tabular} & 127,5 & $\begin{array}{l}75 \\
120 \\
\end{array}$ & 97,5 & 192 & 31,75 & Diperlukan perbaikar \\
\hline & Dry End 2 & 34 & $\begin{array}{ll}94 \\
104 \\
\end{array}$ & 99 & $\begin{array}{l}69 \\
74 \\
\end{array}$ & 71,5 & 186 & 24,02 & $\begin{array}{c}\text { Tidak terjadi } \\
\text { kelelahan }\end{array}$ \\
\hline & Dry End 3 & 29 & \begin{tabular}{l|l|}
81 \\
120 \\
\end{tabular} & 100,5 & $\begin{array}{l}58 \\
65 \\
\end{array}$ & 61,5 & 191 & 30,12 & Diperlukan perbaikar \\
\hline & Chemical 1 & 33 & $\begin{array}{l}87 \\
95\end{array}$ & 91 & $\begin{array}{l}84 \\
79\end{array}$ & 81,5 & 187 & 9,00 & $\begin{array}{c}\text { Tidak terjadi } \\
\text { kelelahan }\end{array}$ \\
\hline & Chemical 2 & 41 & $\begin{array}{l}95 \\
100\end{array}$ & 97,5 & $\begin{array}{l}76 \\
95\end{array}$ & 85,5 & 179 & 12,83 & $\begin{array}{c}\text { Tidak Terjadi } \\
\text { kelelahan }\end{array}$ \\
\hline & Chemical 3 & 25 & $\begin{array}{l}85 \\
95 \\
\end{array}$ & 90 & $\begin{array}{l}75 \\
76 \\
\end{array}$ & 75,5 & 195 & 12,13 & $\begin{array}{c}\text { Tidak terjadi } \\
\text { kelelahan }\end{array}$ \\
\hline & Winder 1 & 44 & $\begin{array}{l}100 \\
109 \\
\end{array}$ & 104,5 & $\begin{array}{l}67 \\
87 \\
\end{array}$ & 77 & 176 & 27,78 & $\begin{array}{c}\text { Tidak Terjadi } \\
\text { kelelahan }\end{array}$ \\
\hline & Winder 2 & 28 & $\begin{array}{l}106 \\
112 \\
\end{array}$ & 109 & \begin{tabular}{|l|}
86 \\
94 \\
\end{tabular} & 90 & 192 & 18,63 & $\begin{array}{c}\text { Tidak terjadi } \\
\text { kelelahan }\end{array}$ \\
\hline & Winder 3 & 26 & $\begin{array}{l}101 \\
109 \\
\end{array}$ & 105 & $\begin{array}{l}70 \\
74 \\
\end{array}$ & 72 & 194 & 27,05 & $\begin{array}{c}\text { Tidak Terjadi } \\
\text { kelelahan }\end{array}$ \\
\hline & Winder 4 & 24 & $\begin{array}{l}93 \\
99 \\
\end{array}$ & 96 & $\begin{array}{l}65 \\
90\end{array}$ & 77,5 & 196 & 15,61 & $\begin{array}{c}\text { Tidak terjadi } \\
\text { kelelahan }\end{array}$ \\
\hline & Winder 5 & 28 & \begin{tabular}{|l|}
80 \\
88 \\
\end{tabular} & 84 & $\begin{array}{l}75 \\
74 \\
\end{array}$ & 74,5 & 192 & 8,09 & $\begin{array}{c}\text { Tidak Terjadi } \\
\text { kelelahan }\end{array}$ \\
\hline & Winder 6 & 50 & $\begin{array}{l}86 \\
90 \\
\end{array}$ & 88 & $\begin{array}{l}72 \\
81 \\
\end{array}$ & 76,5 & 170 & 12,30 & $\begin{array}{c}\text { Tidak terjadi } \\
\text { kelelahan }\end{array}$ \\
\hline & Thimons 1 & 46 & \begin{tabular}{|l|}
93 \\
122 \\
\end{tabular} & 107,5 & $\begin{array}{l}80 \\
96\end{array}$ & 88 & 174 & 22,67 & $\begin{array}{c}\text { Tidak Terjadi } \\
\text { kelelahan }\end{array}$ \\
\hline
\end{tabular}

Sumber: Pengolahan data CVL, 2021

Tabel 3.3. Perhitungan persentase CVL shift 3 grup B

\begin{tabular}{|c|c|c|c|c|c|c|c|c|c|}
\hline Grup & Nama & Umur & DNK & \begin{tabular}{|c|} 
DNK \\
rata-rata
\end{tabular} & DNI & \begin{tabular}{|c|} 
DNI \\
rata-rata
\end{tabular} & $\begin{array}{c}\text { DN } \\
\text { max }\end{array}$ & $\% \mathrm{CVL}$ & Keterangan \\
\hline \multirow{16}{*}{ B } & Wet End 1 & 34 & $\begin{array}{l}97 \\
122\end{array}$ & 109,5 & $\begin{array}{l}70 \\
82\end{array}$ & 76 & 186 & 30,45 & $\begin{array}{c}\text { Diperlukan } \\
\text { perbaikan }\end{array}$ \\
\hline & Wet End 2 & 32 & 110 & 122,5 & $\begin{array}{l}86 \\
87\end{array}$ & 86,5 & 188 & 35,47 & Diperlukan \\
\hline & Wet End 3 & 30 & $\begin{array}{l}99 \\
155\end{array}$ & 127 & $\frac{73}{79}$ & 76 & 190 & 44,74 & $\begin{array}{l}\text { Diperlukan } \\
\text { perbaikan }\end{array}$ \\
\hline & Dry End 1 & 28 & $\frac{121}{130}$ & 125,5 & $\frac{94}{97}$ & 95,5 & 192 & 31,09 & $\begin{array}{l}\text { Diperlukan } \\
\text { perbaikan }\end{array}$ \\
\hline & Dry End 2 & 30 & $\begin{array}{l}97 \\
114 \\
\end{array}$ & 105,5 & $\frac{85}{90}$ & 87,5 & 190 & 17,56 & $\begin{array}{c}\text { Tidak terjadi } \\
\text { kelelahan }\end{array}$ \\
\hline & Dry End 3 & 26 & $\begin{array}{l}101 \\
142\end{array}$ & 121,5 & $\begin{array}{l}62 \\
95\end{array}$ & 78,5 & 194 & 37,23 & $\begin{array}{c}\text { Diperlukan } \\
\text { perbaikan }\end{array}$ \\
\hline & Chemical 1 & 28 & $\begin{array}{l}80 \\
91 \\
\end{array}$ & 85,5 & \begin{tabular}{|l|}
68 \\
72 \\
\end{tabular} & 70 & 192 & 12,70 & $\begin{array}{c}\begin{array}{c}\text { Tidak terjadi } \\
\text { kelelahan }\end{array} \\
\end{array}$ \\
\hline & Chemical 2 & 33 & $\begin{array}{l}105 \\
116\end{array}$ & 110,5 & $\frac{101}{90}$ & 95,5 & 187 & 16,39 & $\begin{array}{c}\text { Tidak Terjadi } \\
\text { kelelahan }\end{array}$ \\
\hline & Chemical 3 & 36 & $\begin{array}{l}75 \\
84 \\
\end{array}$ & 79,5 & $\begin{array}{l}66 \\
72 \\
\end{array}$ & 69 & 184 & 9,13 & $\begin{array}{c}\begin{array}{c}\text { Tidak terjadi } \\
\text { kelelahan }\end{array} \\
\text {. }\end{array}$ \\
\hline & Winder 1 & 45 & $\begin{array}{l}109 \\
134 \\
\end{array}$ & 121,5 & $\begin{array}{ll}67 \\
112 \\
\end{array}$ & 89,5 & 175 & 37,43 & $\begin{array}{c}\text { Diperlukan } \\
\text { perbaikan }\end{array}$ \\
\hline & Winder 2 & 33 & $\begin{array}{l}99 \\
155 \\
\end{array}$ & 127 & $\begin{array}{l}86 \\
94 \\
\end{array}$ & 90 & 187 & 38,14 & $\begin{array}{r}\text { Diperlukan } \\
\text { perbaikan }\end{array}$ \\
\hline & Winder 3 & 27 & $\begin{array}{l}102 \\
121 \\
\end{array}$ & 111,5 & $\begin{array}{l}81 \\
92 \\
\end{array}$ & 86,5 & 193 & 23,47 & $\begin{array}{c}\text { Tidak terjadi } \\
\text { kelelahan }\end{array}$ \\
\hline & Winder 4 & 38 & \begin{tabular}{c|}
98 \\
120
\end{tabular} & 109 & $\begin{array}{l}90 \\
90\end{array}$ & 90 & 182 & 20,65 & $\begin{array}{c}\begin{array}{c}\text { Tidak terjadi } \\
\text { kelelahan }\end{array} \\
\text {. }\end{array}$ \\
\hline & Winder 5 & 24 & $\begin{array}{l}105 \\
124 \\
\end{array}$ & 114,5 & $\begin{array}{l}68 \\
95 \\
\end{array}$ & 81,5 & 196 & 28,82 & $\begin{array}{c}\text { Tidak Terjadi } \\
\text { kelelahan }\end{array}$ \\
\hline & Winder 6 & 27 & \begin{tabular}{|l|}
97 \\
109
\end{tabular} & 103 & $\begin{array}{l}69 \\
77\end{array}$ & 73 & 193 & 25,00 & $\begin{array}{c}\begin{array}{c}\text { Tidak terjadi } \\
\text { kelelahan }\end{array} \\
\text { (a) }\end{array}$ \\
\hline & Thimons 1 & 53 & $\begin{array}{l}110 \\
145\end{array}$ & 127,5 & $\begin{array}{l}89 \\
97 \\
\end{array}$ & 93 & 167 & 46,62 & $\begin{array}{c}\text { Diperlukan } \\
\text { perbaikan }\end{array}$ \\
\hline
\end{tabular}

Sumber: Pengolahan data CVL, 2021

\subsection{Pengukuran beban kerja mental dengan menggunakan metode Subjective Workload Assesment Technique (SWAT)}

\section{A. Pengumpulan data kuisioner}

Perolehan data dari respoden yang telah mengisi kuisioner SWAT, Subjek atau responden tersebut adalah Kepala shift yang berjumlah 4 orang dari 4 grup dan Operator Dekstop Control System (DCS) yang berjumlah 4 orang dari 4 grup bagian produksi pada seksi Paper mesin \#6. Sampel diambil secara acak dari masing-masing subjek sehingga probabilitas yang diperoleh setiap subjek sama.

Terdapat 2 (dua) model pada kuisioner SWAT yang digunakan. Model pertama yaitu Pairwise Comparison Procedure untuk pembuatan skala dan yang kedua adalah pemberian nilai beban kerja yang dialami oleh responden pada pekerjaan yang dilakukan.

B. Pengembangan Skala (Scale Development) Pada fase ini responden diberikan pilihan untuk melakukan pengurutan kartu kombinasi SWAT yang berjumlah 27 kartu dengan tiga variabel deskripsi beban kerja yaitu Time, Effort dan Stress. dimulai dari tingkatan dengan kategori yang paling rendah hingga kategori yang paling tinggi. mulai. Hal ini dilakukan untuk mendapatkan hasil beban kerja pada masingmasing individu.

1. Hasil pengurutan kombinasi kartu SWAT oleh Kepala shift

Hasil pengurutan kombinasi kartu SWAT oleh 4 orang Kepala shift dari 4 Grup adalah sebagai berikut :

Tabel 3.4. hasil pengurutan kombinasi kartu SWAT oleh kepala shift

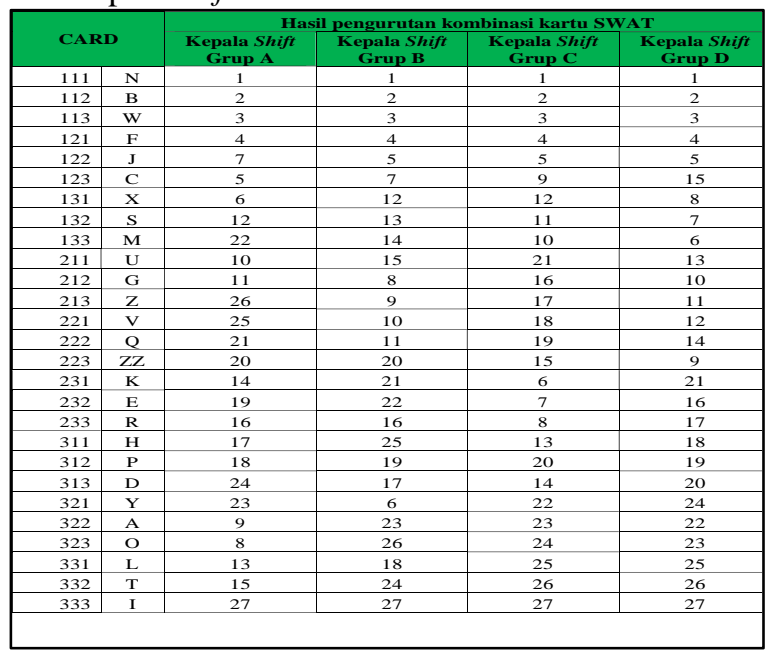

Sumber: Pengolahan data SWAT, 2021

Hasil prototype dan koefisien kendal menggunakan software SWAT adalah sebagai berikut: 


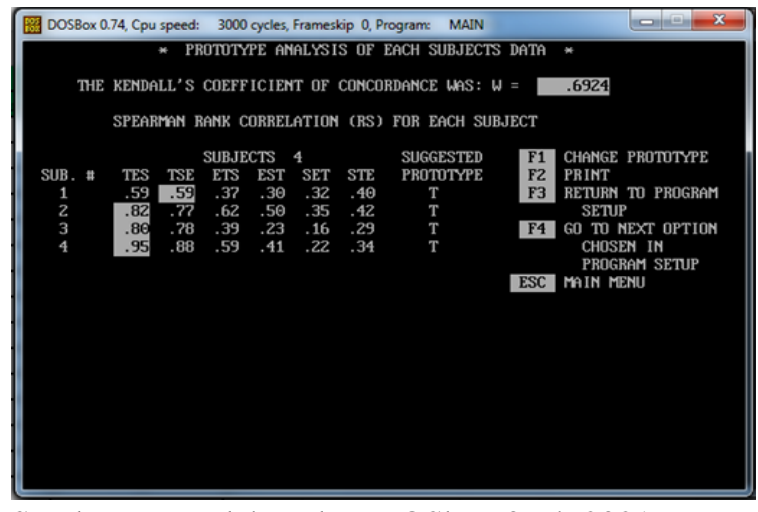

Sumber: Pengolahan data DOSbox 0.74, 2021

Tabel 3.5. Individual Scaling Solution (ISS)

\begin{tabular}{|c|c|c|c|}
\hline Responden & $\begin{array}{c}\text { Time } \\
(\mathbf{T})\end{array}$ & $\begin{array}{c}\text { Effort } \\
\text { (E) }\end{array}$ & $\begin{array}{c}\text { Stress } \\
\text { (S) }\end{array}$ \\
\hline Kepala Shift Grup A & $61,25 \%$ & $24,88 \%$ & $13,88 \%$ \\
\hline Kepala Shift Grup B & $54,25 \%$ & $28,36 \%$ & $17,39 \%$ \\
\hline Kepala Shift Grup C & $71,40 \%$ & $26,43 \%$ & $2,10 \%$ \\
\hline Kepala Shift Grup D & $54,80 \%$ & $38,90 \%$ & $6,30 \%$ \\
\hline
\end{tabular}

Sumber: Pengolahan data SWAT, 2021

2. Hasil pengurutan kombinasi kartu SWAT oleh operator DCS

Hasil pengurutan kartu SWAT oleh 4 orang Operator DCS adalah sebagai berikut:

Tabel 3.6. hasil pengurutan kombinasi kartu SWAT oleh operator DCS

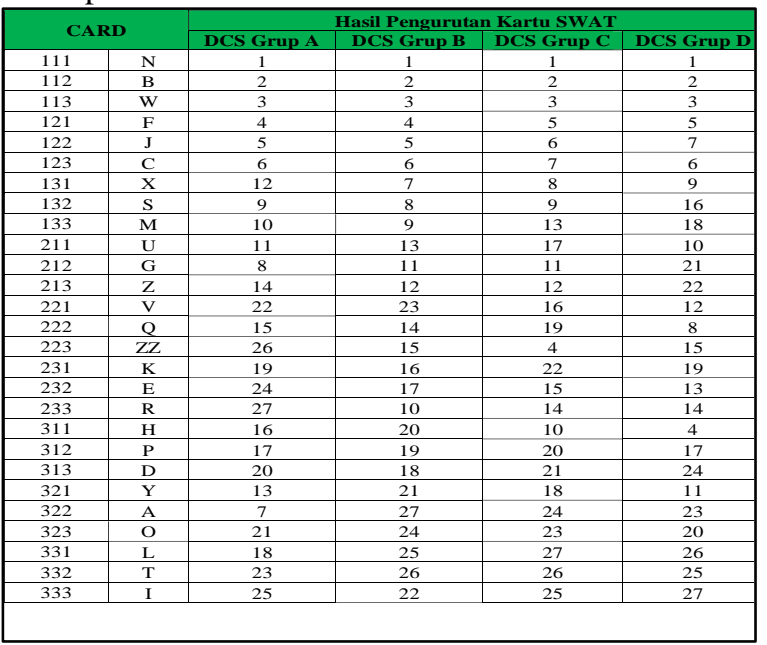

Sumber: Pengolahan data SWAT, 2021

Hasil prototype dan koefisien kendal menggunakan software SWAT adalah sebagai berikut:

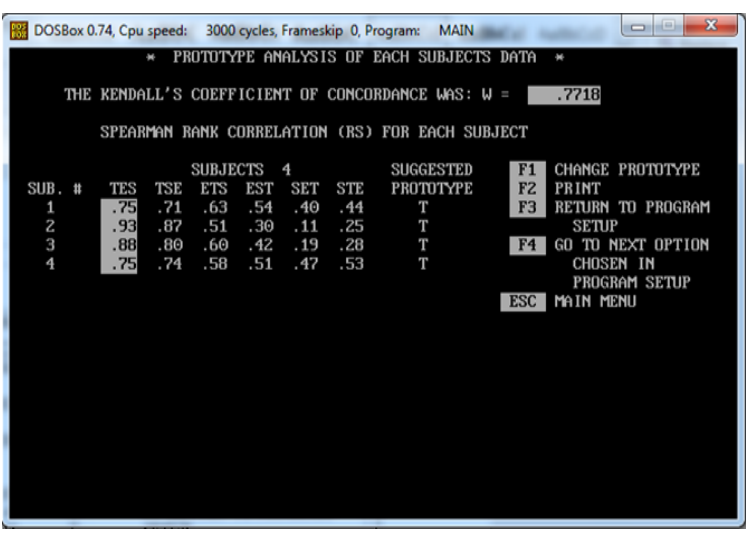

Sumber: Pengolahan data DOSbox 0.74, 2021

Tabel 3.7. Group Scaling Solution (GSS)

\begin{tabular}{|c|c|c|c|c|c|}
\hline \multirow[b]{2}{*}{ No. } & \multirow[b]{2}{*}{ Huruf } & \multicolumn{3}{|c|}{ Kombinasi beban kerja } & \multirow{2}{*}{ Nilai skala karyawan } \\
\hline & & $\begin{array}{l}\text { Time } \\
(T)\end{array}$ & $\begin{array}{l}\text { Effort } \\
\text { (E) }\end{array}$ & $\begin{array}{l}\text { Stress } \\
(\text { S })\end{array}$ & \\
\hline 1 & $\mathbf{N}$ & 1 & 1 & 1 & 0 \\
\hline 2 & B & 1 & 1 & 2 & 3,1 \\
\hline 3 & $\mathrm{~W}$ & 1 & 1 & 3 & 8,1 \\
\hline 4 & $\mathrm{~F}$ & 1 & 2 & 1 & 12,7 \\
\hline 5 & $\mathbf{J}$ & 1 & 2 & 2 & 15,9 \\
\hline 6 & $\mathrm{C}$ & 1 & 2 & 3 & 20,9 \\
\hline 7 & $\mathrm{x}$ & 1 & 3 & 1 & 23,3 \\
\hline 8 & $\mathrm{~s}$ & 1 & 3 & 2 & 26,4 \\
\hline 9 & M & 1 & 3 & 3 & 31,4 \\
\hline 10 & $\mathrm{U}$ & 2 & 1 & 1 & 50,4 \\
\hline 11 & G & 2 & 1 & 2 & 53,5 \\
\hline 12 & $\mathrm{Z}$ & 2 & 1 & 3 & 58,5 \\
\hline 13 & $\mathrm{~V}$ & 2 & 2 & 1 & 63,1 \\
\hline 14 & $\mathrm{Q}$ & 2 & 2 & 2 & 66,2 \\
\hline 15 & $\mathrm{ZZ}$ & 2 & 2 & 3 & 68,6 \\
\hline 16 & $\mathrm{~K}$ & 2 & 3 & 1 & 71,2 \\
\hline 17 & $E$ & 2 & 3 & 2 & 71,7 \\
\hline 18 & $\mathbf{R}$ & 2 & 3 & 3 & 73,7 \\
\hline 19 & $\mathbf{H}$ & 3 & 1 & 1 & 76,7 \\
\hline 20 & $\mathrm{P}$ & 3 & 1 & 2 & 76,8 \\
\hline 21 & $\mathrm{D}$ & 3 & 1 & 3 & 81,3 \\
\hline 22 & $Y$ & 3 & 2 & 1 & 81,8 \\
\hline 23 & A & 3 & 2 & 2 & 84,4 \\
\hline 24 & $\mathrm{O}$ & 3 & 2 & 3 & 89,4 \\
\hline 25 & L & 3 & 3 & 1 & 91,9 \\
\hline 26 & $T$ & 3 & 3 & 2 & 95 \\
\hline 27 & I & 3 & 3 & 3 & 100 \\
\hline
\end{tabular}

Sumber: Pengolahan data SWAT, 2021

Tabel 3.8. hasil konversi Event scoring operator DCS

\begin{tabular}{|c|l|c|c|c|c|}
\hline \multirow{2}{*}{ No } & \multicolumn{2}{|c|}{ Deskripsi pekerjaan } & \multicolumn{4}{c|}{ Operator DCS } \\
\cline { 3 - 6 } & & Grup A & Grup B & Grup C & Grup D \\
\hline 1 & $\begin{array}{l}\text { Mengoperasikan alat di lapangan melalui } \\
\text { komputer dan memantau personil dan alat di } \\
\text { lapangan dalam keadaan aman untuk di runing }\end{array}$ & 23,3 & 0 & 81,8 & 66,2 \\
\hline 2 & Mengecek masalah di lapangan melalui monitor & 15,9 & 66,2 & 15,9 & 66,2 \\
\hline 3 & $\begin{array}{l}\text { Memonitor aktual kertas di lapangan melalui } \\
\text { WBM kamera }\end{array}$ & 15,9 & 50,4 & 89,4 & 63,1 \\
\hline 4 & Mengatur komposisi material yang akan di mix & 31,4 & 66,2 & 100 & 100 \\
\hline 5 & Komunikasi dengan tim Quality Control & 15,9 & 0 & 81,3 & 66,2 \\
\hline 6 & $\begin{array}{l}\text { Komunikasi dengan divisi terkait (Power } \\
\text { supply, Pulp making, GCC/PCC supply, dII) }\end{array}$ & 15,9 & 0 & 84,4 & 71,2 \\
\hline 7 & $\begin{array}{l}\text { Memastikan kondisi di lapangan dengan di } \\
\text { monitor sinkron }\end{array}$ & 66,2 & 0 & 100 & 66,2 \\
\hline 8 & $\begin{array}{l}\text { Mengkoordinasikan dengan pihak terkait bila } \\
\text { terjadi masalah di lapangan }\end{array}$ & 66,2 & 0 & 76,8 & 100 \\
\hline 9 & $\begin{array}{l}\text { Menulis laporan dari awal shift hingga serah } \\
\text { terima shift kepada shift selanjutnya }\end{array}$ & 66,2 & 0 & 12,7 & 66,2 \\
\hline
\end{tabular}

Sumber: Pengolahan data SWAT, 2021

SURYA TEKNIKA Vol. 8 No. 2, Desember 2021: 302-309 


\section{KESIMPULAN}

1. Dari hasil perhitungan menggunakan metode Cardiovascular load bahwa beban kerja fisik yang terbesar terjadi pada Shift 1 grup D dirasakan oleh operator dari stasiun Winder 2 dengan nilai \% CVL sebesar 32,91\% dengan rekomendasi diperlukan perbaikan. Untuk Shift 2 grup A operator Dry End 1 dengan nilai \% CVL terbesar yaitu dengan persentasi $31,75 \%$ dengan rekomendasi diperlukan perbaikan. Selanjutnya pada shift 3 grup B operator Thimon 1 memiliki nilai \% CVL tertinggi yakni sebesar 46,62\% dengan rekomendasi diperlukan perbaikan. Kemudian berdasarkan perhitungan, maka ada sebanyak 3 orang karyawan mengalami beban kerja fisik dalam kategori diperlukan perbaikan saat shift 1, 2 orang operator mengalami beban kerja fisik dengan kategori diperlukan perbaikan pada shift 2, dan 7 orang operator mengalami beban kerja fisik dengan kategori diperlukan perbaikan pada Paper mesin \#6.

2. Hasil dari metode SWAT untuk Kepala shift, Nilai koefisien Kendall yang diperoleh adalah 0,6924 atau <0,75. Skala yang dihasilkan tidak dapat mewakili beban kerja kelompok, Individual Scaling Solution (ISS) adalah metode yang paling cocok guna menentukan skala pengukuran beban kerja, Dimensi yang paling berpengaruh adalah Time Load dengan nilai rata-rata beban yang berkontribusi paling besar yaitu dimensi time $60,44 \%$, artinya menunjukkan bahwa pekerja secara signifikan merasakan beban waktu lebih dominan mempengaruhi pekerjaannya. Hasil dari perhitungan SWAT untuk Operator Dekstop Control System (DCS), Nilai Koefisien Kendall's yang didapat adalah 0,7718 atau $>0,75$. Skala yang di hasilkan dapat mewakili beban kerja kelompok, Group Scaling Solution (GSS) adalah metode yang tepat dalam menentukan skala pengukuran beban kerja, Dimensi waktu ialah perihal yang sangat mempengaruhi terhadap kondisi beban kerja mental. Perihal ini dapat dilihat dari rata-rata nilai beban yang berkontribusi besar dalam beban kerja kognitif merupakan dimensi Time dengan nilai $68,57 \%$

\section{DAFTAR PUSTAKA}

[1] Susanti, D. A., \& Pangesti, D. (2021). Analisis Beban Kerja Fisik Menggunakan Metode Cardiovascular Load (CVL) pada Area Finishing (Studi Kasus di Salah Satu Perusahaan Logam di Klaten, Jawa Tengah). 5(1), 13-18.

[2] Munte, S., Hasibuan, C. F., Studi, P., \& Industri, T. (2021). Analysis of the Workload Measurement by Using. 5(1), 65-71.

[3] Krisnaningsih, D. (2019). Pengukuran Beban Kerja Mental Operator Control Room Menggunakan Metode Subjective Workload Assesment Technique (SWAT) di PT. Krakatau Steel (Persero) TBK. Jurnal InTent, 2(1), 32-44. http://ejournal.lppmunbaja.ac.id/index.php/intent/article/view/50 7

[4] Rizalmi, S. R., \& Utami, I. W. (2020). Analisis Beban Kerja Kognitif Dengan Menggunakan Metode Subjective Workload Assessment Technique (SWAT) Pada Karyawan Departemen Quality .... Journal Science Innovation and Technology ..., 1, 30-35.

http://ojs.udb.ac.id/index.php/SINTE CH/article/download/875/876

[5] Pratama, Ricko Galih dan hutabarat, julianus dan kiswandono. (2020). Pengukuran Beban Kerja Mental Karyawan dengan Metode Subjective Workload Assessment Technique (SWAT) pada Gudang Logistik di PT. Molindo Inti Gas. Jurnal Valtech (Jurnal Mahasiswa Teknik Industri), 3(1), 88-92. http://eprints.itn.ac.id/4659/ 